\title{
Water Use Efficiency of Drip Fertigated Sweet Pepper under the Influence of Different Kinds and Levels of Fertilizers
}

\author{
Roma Kumari*, Arun Kaushal and K.G. Singh \\ Department of Soil and Water Engineering, Punjab Agricultural University, Ludhiana, India; roma0738@gmail.com
}

\begin{abstract}
A field experiment was conducted to study the influence of different kinds and levels of fertilizers on water use efficiency of drip fertigated Sweet pepper at the Research Farm of the Department of Soil and Water Engineering, PAU, Ludhiana in the year 2012-2013. In the drip fertigation experiment, two types of fertilizers viz. Water Soluble Fertilizers (specialized fertilizers, WSF) and conventional fertilizers and three doses of NPK fertilizers were applied by drip irrigation. The drip fertigated treatments were $\mathrm{T}_{1}$ (WSF applied at $80 \%$ RDF (recommended dose of fertilizer)), $\mathrm{T}_{2}$ (WSF applied at 70\% RDF), $\mathrm{T}_{3}$ (WSF applied at 60\% RDF), $\mathrm{T}_{4}$ (Conventional fertilizer applied at $80 \% \mathrm{RDF}$ ), $\mathrm{T}_{5}$ (Conventional fertilizer applied at $70 \%$ $\mathrm{RDF}$ ) and $\mathrm{T}_{6}$ (Conventional fertilizer applied at $60 \% \mathrm{RDF}$ ) and an additional control treatment (with furrow irrigation and $100 \%$ traditional fertilizer) was used for comparison. The irrigation was applied at $75 \% \mathrm{ET}_{C}$. The percentage water saving for drip fertigation treatment was $33.94 \%$ over the conventional irrigation. Out of all the treatments, water use efficiency for $\mathrm{T}_{2}$ treatment was maximum $(5.24 \mathrm{q} / \mathrm{ha}-\mathrm{cm})$ which was significantly par with $\mathrm{T}_{4}(5.19 \mathrm{q} / \mathrm{ha}-\mathrm{cm})$ treatment. The minimum water use efficiency was in conventional method $(2.69 \mathrm{q} / \mathrm{ha}-\mathrm{cm})$. While, for drip fertigated treatments, the minimum water use efficiency was in $\mathrm{T}_{6}$ treatment $(3.25 \mathrm{q} / \mathrm{ha}-\mathrm{cm})$.The statistical analysis showed that the water use efficiency of $\mathrm{T}_{2}$ and $\mathrm{T}_{4}$ treatment were significantly superior than all other treatments.
\end{abstract}

Keywords: Drip Irrigation, Fertigation, Sweet Pepper, Water Use Efficiency

\section{Introduction}

Water is a vital component for successful vegetable production ${ }^{1}$. The increased competition for water between agricultural, industrial, and urban consumers creates the need for continuous improvement of irrigation practices in commercial vegetable production ${ }^{2}$. Generally, vegetables crops require and consume comparatively more water owing to increase number of harvests.

Sweet pepper is one of the most popular and high value vegetable crops grown for its immature fruits throughout the world. Sweet pepper consumption in India has increased now- a- days due to increased demand by urban consumers. Water has been identified as one of the scarcest inputs, which can severely restrict agricultural growth unless it is carefully conserved and managed ${ }^{3}$. According to National Academy of Agricultural Sciences, water-table in 82 per cent area of Punjab has gone down substantially. The net annual groundwater draft in Punjab exceeds availability by 45 per cent. Based on the water table data collected regularly, it was brought out that in 9,058 sq km of central Punjab it has gone down by more than 20 metres in the past one decade and the trend is continuing with some districts ${ }^{4}$. Due to water scarcity, the available water resources should be very effectively utilized through water saving irrigation technologies. Hence in the present day context, lot of emphasis is being given in improving the irrigation practices to increase the crop production and to sustain the productivity levels. Maximizing of the yield is also essential to serve the increasing population of the country. Therefore, adoption of modern irrigation techniques is needed to be emphasized to increase water use efficiency and covering more area under cultivation. Furrow and basin irrigation

${ }^{*}$ Author for correspondence 
methods are commonly adopted to irrigate vegetables crops, which causes adverse effects of cyclic over irrigation and water stress ${ }^{5}$. Drip irrigation is the most effective way to supply water and nutrients to the plants not only save water but also increases yield of fruit and vegetable crops $^{6}$. It improves yield as well as quality of produce with appreciable water saving. Use of drip irrigation coupled with fertigation is gaining much importance, which act as slow release of fertilizer and hence nutrients are available to the plants over long period of growth, results in increase in crop growth and yield ${ }^{7}$. Drip fertigation allows nutrient placement directly into the root zone around the plants through the emitters near plant roots during critical periods of nutrient requirement ${ }^{8}$.

Now a days, many types of fertilizers including specialized fertilizers and conventional fertilizers are available in the market to be applied through drip irrigation but, which fertilizers and at what dose must be applied is a problem for the farmers, hence present study was carried out to see the effects of water soluble fertilizers (specialized fertilizers) with conventional fertilizers on water use efficiency of drip irrigated sweet pepper.

\section{Materials and Methods}

The field experiment was carried out at the Research Farm of the Department of Soil and Water Engineering, PAU, Ludhiana, India ( Latitude $30^{\circ} 56^{\prime} \mathrm{N}$, Longitude $75^{\circ}$ 52' E and situated at 247 meters above mean sea level) during the months of October-June( 2012-2013). The experimental soil was sandy clay loam, low in available $\mathrm{N}$, medium in available $\mathrm{P}\left(31.62 \mathrm{~kg} \mathrm{ha}^{-1}\right)$ and high in available $\mathrm{K}\left(273 \mathrm{~kg} \mathrm{ha}^{-1}\right)$. The soil had maximum $\mathrm{pH}$ value of 8.7, organic carbon content of 0.24 per cent and EC of $0.22 \mathrm{dS} / \mathrm{m}$ on different soil depth. The experiment was laid out in randomized block design and replicated thrice. In the drip fertigation experiment, two types of fertilizers viz. Water Soluble Fertilizers (specialized fertilizers, WSF) and conventional fertilizers and three doses of NPK fertilizers were applied by drip irrigation. The Water Soluble Fertilizers (specialized fertilizers, WSF) consisted of Ammonium Sulphate (N:P:K, 21-00),Phosphoric Acid (N:P:K ,0-80-0), Potassium Sulphate (N:P:K,0:0:50) and the Conventional Fertilizers consisted of Urea (N:P:K ,46:0:0), Monoammonium Phosphate (N:P:K,12:61:0) and Muriate of Potash (N:P:K, 0:0:60). The drip fertigated treatments were $\mathrm{T}_{1}$ (WSF applied at $80 \% \mathrm{RDF}$ (recommended dose of fertilizer)) which is
(125:70:30) $\mathrm{kg} \mathrm{ha}^{-1}$ for the sweet pepper as recommended by PAU, Ludhiana ${ }^{9}, \mathrm{~T}_{2}$ (WSF applied at $70 \% \mathrm{RDF}$ ), $\mathrm{T}_{3}$ (WSF applied at $60 \% \mathrm{RDF}$ ), $\mathrm{T}_{4}$ (Conventional fertilizer applied at $80 \% \mathrm{RDF}$ ), $\mathrm{T}_{5}$ (Conventional fertilizer applied at $70 \% \mathrm{RDF}$ ) and $\mathrm{T}_{6}$ (Conventional fertilizer applied at $60 \% \mathrm{RDF}$ ) and an additional control treatment (with furrow irrigation and $100 \%$ traditional fertilizer as being presently adopted by Punjab state farmers) was used for comparison.

Sweet Pepper seedlings of Indra variety from raised nursery (which was raised in second week of October, 2012) were transplanted at $45 \mathrm{~cm} X 30 \mathrm{~cm}$ spacing on raised bed of $60 \mathrm{~cm}$ width with a spacing $60 \mathrm{~cm}$ between each bed in experimental field on $17^{\text {th }}$ November, 2012 . Sweet pepper is more sensitive to environment (particularly soil temperature and moisture). It was reported by Anonymous $^{9}$ that the Sweet pepper crop grow at soil temperatures between $18^{\circ} \mathrm{C}$ and $35^{\circ} \mathrm{C}$. A few days after transplanting of crop, the sweet pepper crop was covered with 50 microns thickness poly sheet on $28^{\text {th }}$ Nov, 2012 with $185 \mathrm{~cm}$ width over the low tunnel frame heights of $60 \mathrm{~cm}$ above ground to protect crop from frost and other injury. The low tunnel cover was kept up to $23^{\text {rd }}$ February, 2013 and after that low tunnels were removed. The amount of water actually applied by way of drip irrigation system was based on meteorological data such as open pan evaporation, rainfall, sunshine hours, relative humidity, wind speed, temperature (Table 1).

Irrigation to all the treatments was scheduled based on $75 \% \mathrm{ET}_{\mathrm{C}}$ as found to best by Singh et al. ${ }^{10}$. Irrigation was applied every alternate day. The Reference evapotranspiration had been computed using the FAO-56 Penman Monteith equation as discussed by Allen et al. ${ }^{11}$ in the following form:

$$
E T_{0}=\frac{0.408 \Delta\left(R_{n}-G\right)+\gamma \frac{900}{T+273} u_{2}\left(e_{s}-e_{a}\right)}{\Delta+\gamma\left(1+0.34 u_{2}\right)}
$$

Where,

$$
\begin{aligned}
\mathrm{ET}_{0}= & \text { Reference evapotranspiration in mm } \\
\mathrm{R}_{\mathrm{n}}= & \text { Net radiation }\left(\mathrm{MJ} \mathrm{m}^{-2} \text { day }^{-1}\right) \\
\mathrm{G}= & \text { Soil heat flux density }\left(\mathrm{MJ} \mathrm{m}^{-2} \text { day }^{-1}\right) \\
\mathrm{T}= & \text { Mean daily air temperature at } 2 \mathrm{~m} \text { height }\left({ }^{\circ} \mathrm{C}\right) \\
\Delta= & \text { Slope of the saturated vapour pressure } \\
& \text { curve }\left(\mathrm{k} \mathrm{Pa}^{\circ} \mathrm{C}^{-1}\right) \\
\gamma= & \text { Psychometric constant }\left(\mathrm{k} \mathrm{Pa}^{\circ} \mathrm{C}^{-1}\right)
\end{aligned}
$$


Table 1. Meteorological parameters observed during crop growing period

\begin{tabular}{|c|c|c|c|c|c|c|c|c|}
\hline Month & $\begin{array}{l}\mathrm{T}_{\max } \text { Daily } \\
\text { avg }\left({ }^{\mathrm{O}} \mathrm{C}\right)\end{array}$ & $\begin{array}{l}\mathrm{T}_{\min } \text { Daily } \\
\text { avg }\left({ }^{\mathrm{O}} \mathrm{C}\right)\end{array}$ & $\begin{array}{l}\text { Sun-shine } \\
\text { hours } \\
\text { Daily avg }\end{array}$ & $\begin{array}{l}\text { Rainfall } \\
(\mathrm{mm})\end{array}$ & $\begin{array}{l}\text { Open pan } \\
\text { evaporation, } \\
\text { Total in } \mathrm{mm}\end{array}$ & $\begin{array}{l}\text { Wind speed } \\
\text { (Daily avg) } \\
(\mathrm{km} / \mathrm{h})\end{array}$ & $\begin{array}{l}\text { Maximum } \\
\text { Relative humidity } \\
\text { (Daily avg) (\%) }\end{array}$ & $\begin{array}{l}\text { Minimum } \\
\text { Relative humidity } \\
\text { (Daily avg) (\%) }\end{array}$ \\
\hline Nov & 26.6 & 10.5 & 6.6 & 0.0 & 60.6 & 1.9 & 91 & 40 \\
\hline Dec & 19.4 & 7.4 & 5.2 & 17.4 & 48.9 & 4.1 & 92 & 58 \\
\hline Jan & 17.0 & 5.1 & 5.2 & 8.2 & 43.6 & 3.6 & 94 & 60 \\
\hline Feb & 20.5 & 9.7 & 6.4 & 96.4 & 56.7 & 4.9 & 98.0 & 67.0 \\
\hline March & 27.6 & 13.2 & 9.2 & 35.6 & 114.0 & 3.9 & 94 & 50 \\
\hline April & 34.2 & 18.3 & 9.1 & 4.4 & 199.9 & 4.3 & 65 & 24 \\
\hline May & 40.6 & 23.0 & 9.7 & 1.2 & 326.4 & 5.7 & 50 & 26 \\
\hline
\end{tabular}

$\mathrm{e}_{\mathrm{s}}=$ Saturated vapour pressure $(\mathrm{kPa})$

$\mathrm{e}_{\mathrm{a}} \quad=$ Actual vapour pressure $(\mathrm{kPa})$

$\mathrm{u}_{2}=$ Wind speed at $2 \mathrm{~m}$ height $\left(\mathrm{m} \mathrm{s}^{-1}\right)$

The crop evapotranspiration was computed as under:

$$
\mathrm{ET}_{\mathrm{c}}=\mathrm{K}_{\mathrm{c}} \mathrm{ET}_{\mathrm{o}}
$$

Where,

$\mathrm{ET}_{\mathrm{c}}=$ Crop evapotranspiration $(\mathrm{mm})$

$\mathrm{K}_{\mathrm{c}}=$ Crop coefficient, The value of Kc for different stages were taken as reported by Dorenbos et al. ${ }^{12}$ The volume of water applied per plant was computed as given below:

$$
v=\frac{0.75 E T_{c} A_{c} A_{w}}{U}
$$

Where,

$\mathrm{V}=$ Volume of water applied per plant in drip irrigation system (litre)

$A_{c}=$ Cropped area $\left(\mathrm{m}^{2}\right)$ which is calculated by row to row spacing $(\mathrm{m}) \times$ plant to plant spacing $\left(\mathrm{m}^{2}\right)$

$\mathrm{A}_{\mathrm{w}}=$ Fractional wetted area which was taken as $75 \%$ as discussed by Mane et al. ${ }^{13}$

$\mathrm{U}=$ Christiansen uniformity coefficient

Time of irrigation is calculated with the help of formula as given below:

$$
T(d r i p)=\frac{N_{p} V}{N_{e} Q}
$$

Where,

$\mathrm{T}($ drip) $=$ Drip Irrigation time (hours)

$\mathrm{N}_{\mathrm{p}}=$ Number of plants served by one lateral

$\mathrm{V}=$ Volume of water applied per plant in drip irrigation system (litre)

$\mathrm{Ne}=$ Number of emitter in one lateral

$\mathrm{Q}=$ Average emitter discharge (litre/hr)

In the control plot, the water was applied by furrow irrigation after $30 \mathrm{~mm}$ net cumulative pan evaporation, which was computed as under:

Where,

$$
\mathrm{T}(\text { furrow })=\frac{d w i}{360 q}
$$

$\mathrm{T}($ furrow $)=$ Furrow irrigation time $(\mathrm{hrs})$

$\mathrm{d}=$ Depth of water to be applied $(\mathrm{cm})$

$1=$ Furrow length $(\mathrm{m})$

$\mathrm{W}=$ Furrow spacing $(\mathrm{m})$

$\mathrm{q}=$ Discharge available at furrow (lps)

In the first two month of growing period of sweet pepper required fertilizer doses of NPK were applied once in a week to all treatments through drip irrigation. After that, fertilizer application was twice in week. All the fertilizers were applied in equal split doses. Total number of fertigation required for whole experiment was 35 . The details of fertilizers in $\mathrm{kg} / \mathrm{ha}$ in drip fertigated treatment as given in Table 2. In the control plot, the fertilizer was applied as according to recommendation of PAU, Ludhaina ${ }^{9}$. 
Table 2. Requirement of fertilizer

\begin{tabular}{|c|c|c|c|c|}
\hline & \multirow{3}{*}{ Type of Fertilizer } & \multicolumn{3}{|c|}{ Fertilizer Doses Treatments } \\
\hline & & $80 \% \mathrm{RDF}$ & $70 \% \mathrm{RDF}$ & $60 \% \mathrm{RDF}$ \\
\hline & & \multicolumn{3}{|c|}{ (Kg/ha) } \\
\hline \multirow{3}{*}{ Water soluble } & Ammonium sulphate & 476.19 & 416.67 & 357.14 \\
\hline & Phosphoric Acid & 70 & 61.25 & 52.5 \\
\hline & Potassium Sulphate & 48 & 42 & 36 \\
\hline \multirow{3}{*}{ Conventional } & Urea & 193.44 & 169.26 & 145.08 \\
\hline & Monoammonium Phosphate & 91.80 & 80.33 & 68.85 \\
\hline & Muriate of Potash & 40 & 35 & 30 \\
\hline
\end{tabular}

Total weight of matured green fruits harvested from each picking in each replication was recorded till final harvest and the total yield of fruits per hectare under different treatments computed per hectare.

The total fruit yield obtained for each treatment was divided by the quantity of water used for each treatment. Water use efficiency was worked out and expressed as:

$$
\mathrm{WUE}=\frac{\text { Yield }}{\text { Total amount of water used }}
$$

The data collected from the present field experiment were subjected to statistical analysis using randomized block design and using ANalysis of VAriance (ANOVA) techniques. The significance of differences was tested at 5 percent levels.

\section{Results and Discussion}

\subsection{Sweet Pepper Yield}

The effects of drip fertigation treatment on Sweet pepper yield are shown in Figure 1. There was no statistically significant yield difference between treatment $\mathrm{T}_{2}(301.94 \mathrm{q} / \mathrm{ha})$ and treatment $\mathrm{T}_{4}(299.14 \mathrm{q} / \mathrm{ha})$. The drip fertigation treatments $\left(T_{2}, T_{4}\right)$ showed a statistically significantly higher yield as compared with all drip fertigated treatment and control furrow irrigated. This may be due to the uniform distribution and adequate availability of nutrients and moisture in the root zone of the crop. The results are in accordance with Gupta et al. ${ }^{1}$, Veeranna et al..$^{14}$ and Kong et al. ${ }^{15}$. The yield of treatments with drip fertigation of $70 \%$ and $80 \%$ of RDF treatments with both types of fertilizers were significantly higher than that of control furrow treatment while $60 \%$ dose produced less yield as compared with control treatment.

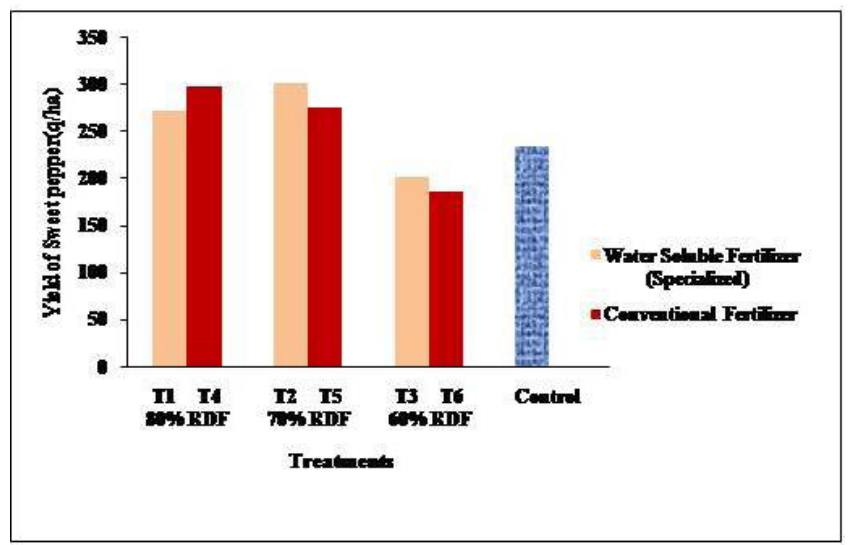

Figure 1. Effect of different treatments on yield of Sweet pepper

\subsection{Irrigation Water Requirement}

Quantity of irrigation water required under different treatments is presented in Table 3. The amount of water applied by drip fertigation was $57.6 \mathrm{~cm}$ with 83 number of irrigation, which was applied with $75 \% \mathrm{ET}_{c}$. The amount of water applied in conventional irrigated control treatment was $87.2 \mathrm{~cm}$. Thus, the water applied in drip fertigation was $33.94 \%$ less as compared to conventional irrigation method. The results are in accordance with that of Fanish ${ }^{16}$, Tanaskovik et al. ${ }^{17}$ and Deolankar et al. ${ }^{18}$ who all reported that the drip irrigated treatments saved considerably amount of water as compared with traditional method of irrigation.

\subsection{Water Use Efficiency}

The data obtained for water use efficiency per ha under different treatments are presented in Table 4. The data clearly revealed that in all the drip fertigated treatments 
Table 3. Irrigation water applied under different treatments

\begin{tabular}{lcccc}
\hline $\begin{array}{l}\text { Irrigation } \\
\text { treatment }\end{array}$ & $\begin{array}{l}\text { Pre irrigation } \\
\text { depth }(\mathrm{cm})\end{array}$ & $\begin{array}{l}\text { Total number } \\
\text { of irrigations }\end{array}$ & $\begin{array}{l}\text { Total depth of irrigation } \\
\text { water applied }(\mathrm{cm})\end{array}$ & $\begin{array}{l}\text { Percentage saving } \\
\text { over furrow irrigation }\end{array}$ \\
\hline $\begin{array}{l}\text { Drip irrigation } \\
\begin{array}{l}\text { Conventional } \\
\text { irrigation }\end{array}\end{array}$ & 3 & 83 & 57.6 & 33.94 \\
\hline
\end{tabular}

water use efficiency was maximum in $\mathrm{T}_{2}$ treatment $(5.24 \mathrm{q} / \mathrm{ha}-\mathrm{cm})$ followed by the allother treatments. Among the conventional drip fertigation treatment, $\mathrm{T}_{4}(5.19 \mathrm{q} /$ ha-cm) gave the maximum water use efficiency followed by $\mathrm{T}_{5}(4.8 \mathrm{q} / \mathrm{ha}-\mathrm{cm})$ and $\mathrm{T}_{6}(3.25 \mathrm{q} /$ ha-cm $)$ treatments. Among the water soluble drip fertigation treatment $\mathrm{T}_{2}(5.24$ $\mathrm{q} /$ ha-cm) gave the maximum water use efficiency followed by $\mathrm{T}_{1}(4.72 \mathrm{q} / \mathrm{ha}-\mathrm{cm})$ and $\mathrm{T}_{3}(3.51 \mathrm{q} / \mathrm{ha}-\mathrm{cm})$ treatments. Amongst all the treatments, the WUE was maximum (5.24 $\mathrm{q} / \mathrm{ha}-\mathrm{cm})$ in $\mathrm{T}_{2}$ treatment, while it was minimum in $\mathrm{T}_{6}(3.25 \mathrm{q} / \mathrm{ha}-\mathrm{cm})$ treatment. Out of all the treatments, water use efficiency for $\mathrm{T}_{2}$ treatment was maximum $(5.24 \mathrm{q} / \mathrm{ha}-\mathrm{cm})$ which was significantly par with $\mathrm{T}_{4}(5.19 \mathrm{q} /$ ha-cm) treatment. The minimum water use efficiency was in conventional method $(2.69 \mathrm{q} / \mathrm{ha}-\mathrm{cm})$ while, for drip fertigated treatments, the minimum water use efficiency was in $\mathrm{T}_{6}$ treatment $(3.25 \mathrm{q} / \mathrm{ha}-\mathrm{cm})$. When we compare water use efficiency in all drip fertigated treatment with control furrow irrigated treatment.It was observed that all these treatments, water use efficiency were significantly better than control furrow irrigated treatment. This may be due to the fact that optimum level of fertilizer doses enhances the water requirement resulting in better yield. The results are in accordance with Sharma et al. ${ }^{19}$ and Veeranna et al. ${ }^{14}$.
Statistical analysis for different treatments given in Table 4 revealed that there was significant effect of fertigation on WUE. The treatments $\mathrm{T}_{2}$ and $\mathrm{T}_{4}$ gave significantly higher WUE than all other treatments, while there was no significant difference between $\mathrm{T}_{2}$ and $\mathrm{T}_{4}$ treatments with each other.

\section{Conclusion}

The drip fertigated experiment concluded that WUE was maximum $(5.24 \mathrm{q} / \mathrm{ha}-\mathrm{cm})$ in $\mathrm{T}_{2}$ treatment, while it was minimum in $\mathrm{T}_{6}(3.25 \mathrm{q} / \mathrm{ha}-\mathrm{cm})$ treatment. The treatments $\mathrm{T}_{2}$ and $\mathrm{T}_{4}$ gave significantly higher WUE than all other treatments, while there was no significant difference between $\mathrm{T}_{2}$ and $\mathrm{T}_{4}$ treatments with each other.

The WUE of best drip fertigated treatment was $94.79 \%$ more than the control furrow irrigated treatment presently being used by farmers. The best drip fertigation treatment saves $33.94 \%$ of water as well as $20 \%$ of fertilizer as compared to control furrow irrigated method for growing sweet pepper. Hence, drip fertigation by applying $80 \%$ of conventional fertilizer may be adopted in comparison to costly specialized fertilizer available in the market for raising of sweet pepper.

Table 4. Effect of different treatments on water use efficiency

\begin{tabular}{|c|c|c|c|c|}
\hline Irrigation Method & $\begin{array}{l}\text { Type of } \\
\text { Fertilizer }\end{array}$ & $\begin{array}{l}\text { Fertilizer } \\
\text { Dose (\% RDF) }\end{array}$ & Treatments & $\begin{array}{l}\text { Water Use Efficiency } \\
(\mathrm{q} / \mathrm{ha} / \mathrm{cm})\end{array}$ \\
\hline \multirow[t]{6}{*}{ Drip } & \multirow{4}{*}{$\begin{array}{l}\text { Water Soluble } \\
\text { (specialized) }\end{array}$} & 80 & $\mathrm{~T}_{1}$ & 4.72 \\
\hline & & 70 & $\mathrm{~T}_{2}$ & 5.24 \\
\hline & & 60 & $\mathrm{~T}_{3}$ & 3.51 \\
\hline & & 80 & $\mathrm{~T}_{4}$ & 5.19 \\
\hline & \multirow[t]{2}{*}{ Conventional } & 70 & $\mathrm{~T}_{5}$ & 4.80 \\
\hline & & 60 & $\mathrm{~T}_{6}$ & 3.25 \\
\hline \multirow[t]{2}{*}{ Conventional } & Conventional & 100 & & 2.69 \\
\hline & & $\mathrm{CD}(5 \%)$ & 0.41 & \\
\hline
\end{tabular}




\section{References}

1. Gupta AJ, Ahmed MF, Bhat FN. Studies on yield, quality, water and fertilizer use efficiency of capsicum under drip irrigation and fertigation. Ind J Hort. 2010; 67:213-8.

2. Sezen SM, Yazar A, Eker S. Effect of drip irrigation regimes on yield and quality of field grown bell pepper. Agri Water Mgmt. 2006; 81:115-31.

3. Tiwari KN, Singh A, Mal PK. Effect of drip irrigation on yield of cabbage (Brassica oleracea L.var.capitata) under mulch and non-mulch conditions. Agric Water Mgmt. 2003; 58:19-28.

4. Singh J. Depleting water resources of indian punjab agriculture and policy options-A lesson for high potential areas. Global J Sci Front Res Agric Veter. 2013; 13:17-23.

5. Rao AS. Drip Irrigation in India. Indian National Committee on Irrigation and Drainage, Ministry of Water Resources, Government of India; 1994.

6. Tiwari KN, Mal PK, Singh M, Chattopadyay A. Response of okra (Abelmoschus Esculentus L. Moench.) to drip irrigation under mulch and non-mulch conditions. Agric Water Mgmt. 1998; 38:91-102.

7. Rani R, Nirala SK, Suresh R. Effect of Fertigation and Mulch on yield of pointed gourd in calcareous soil of north bihar. Environ Eco. 2012; 30:641-5.

8. Imas P, Bar-Yosef B, Kafkafi U, Gangmore R. Release of carboxylic anions and protons by tomato roots in response to ammonium nitrate ratio and $\mathrm{pH}$ in nutrient solution. Plant and soil. 1997; 197:27-34.

9. Anonymous. Package of Practices for Cultivation of Vegetable Crops. Ludhiana, India: Punjab Agricultural University; 2011.
10. Singh KG, Kaushal A. Annual Progress Report of AICRP on Application of Plastics in Agriculture Punjab Agricultural University, Ludhiana, Punjab, India; 2011.

11. Allen RG, Pereira LS, Raes D, Smith M. Crop evapotranspiration-guidelines for computing crop water requirements. FAO Irrigation and Drainage Paper 56. Rome: 1998.

12. Doorenbos J, Pruitt WO. Guidelines for Predicting Crop Water Requirements. Irrigation and Drainage Paper 24. Rome, Italy: Food and Agriculture Organization of the United Nations; 1975.

13. Mane MS, Ayare BL, Magar SS. Principle of Drip Irrigation System. New Delhi, India: Jain Brothers; 2008.

14. Veeranna HK, Kgalak A, Faroodhi AA, Sujith GM. Effect of fertigation with normal and water soluble fertilizers compared to drip and furrow methods on yield, fertilizer and irrigation water use efficiency in chilli. Micro Irrigation. 2001; 2:461-6.

15. Kong Q, Li G, Wang Y, Huo H. Bell pepper response to surface and subsurface drip irrigation under different fertigation levels. Irrig Sci. 2011; 11:271-8.

16. Fanish SA, Muthukrishnan P. Effect of drip fertigation and intercropping on growth, yield and water use efficiency of maize (Zea mays L.). Madras Agric J. 2011; 98:238-42.

17. Tanaskovik V, Cukaliev O, Romic D, Ondrasek G. The Influence of drip fertigation water use efficiency in tomato crop production. Agric Conspec Sci. 2011; 76:57-63.

18. Deolankar KP, Firake NN. Effect of fertigation on solid soluble fertilizers on growth and yield of chilli. J Maharashtra Agril Univ. 1999; 24:242-3.

19. Sharma S, Halder A, Patra SK, Ray R. Effect of drip irrigation and nitrogen fertigation on water use efficiency (WUE) and cost economics of guava cv. Khaja. Prog Horti. 2012; $44: 136-41$. 